Anja Božic

\title{
"Movere et delectare" after St. Jerome: Pier Paolo Vergerio's Fifth Sermon pro Sancto Hieronymo
}

\section{"Movere et delectare" po sv. Hieronimu: Vergerijev peti govor pro Sancto Hieronymo}

Abstract: The present paper analyzes the personal devotion to St. Jerome as expressed in the works of Pier Paolo Vergerio, one of the leading humanist authors of his generation. Jerome's simultaneous investment in theology and classical learning made him a famed saint among the humanists. By transforming St. Jerome into a model of a pious scholar, Vergerio was, therefore, one of the key proponents in the dissemination of St. Jerome's cult in the Renaissance. Vergerio's ten lively Sermones pro Sancto Hieronymo (1392-1408) are considered the earliest examples of the classicizing orations (panegyrics) in the context of devotional public oratory. Vergerio includes traditional elements of Jerome's hagiography in his orations yet charges them with a personal dimension. Referring to the ancient tradition of his family, Vergerio portrays St. Jerome as their protector and patron saint and commends his recently deceased father into the saint's care. There is, however, no extant information about the family's rituals regarding St. Jerome and Vergerio does not refer to their devotion in all of his orations in honour of the saint. This paper explores Vergerio's creation of a personal cult of St. Jerome and interprets it as a self-fashioning device, aiming to establish Vergerio as an eloquent humanist intellectual.

Keywords: Pier Paolo Vergerio the Elder, St. Jerome, patron saint, epideictic oration, humanist self-fashioning

Povz̧etek: Članek obravnava sv. Hieronima kot osebnega in družinskega zavetnika v slavilnih govorih enega najpomembnejših humanističnih avtorjev svoje generacije, Koprčana Petra Pavla Vergerija Starejšega. Hieronim je zaradi svoje ljubezni tako do Biblije kakor do klasičnih avtorjev postal priljubljen zavetnik humanistov, ki so ga razumeli kot ideal sinteze med krščanstvom in antiko. Vergerij je s prevrednotenjem sv. Hieronima v lik pobožnega učenjaka postal eden glavnih glasnikov Hieronimovega humanističnega kulta. Vergerijev slavospev v čast sv. Hieronimu se razlega iz desetih živahnih govorov Sermones pro Sancto Hieronymo (1392-1408), ki jih je Vergerij spisal po vzoru klasičnega slavilnega 
govorništva. Kljub resda standardnim elementom Hieronimovih hagiografskih upodobitev pa Vergerijevi govori izstopajo zaradi dodatne, osebne note. Humanist sv. Hieronima časti kot osebnega in družinskega zavetnika in mu v skrb priporoča svojega umrlega očeta. Vendar ni znano, da bi Hieronim v resnici veljal za družinskega zavetnika družine Vergerijev, poleg tega pa ga Vergerij ne naslavlja tako v vseh desetih govorih. Članek pojasnjuje Vergerijevo prevzetje sv. Hieronima za osebnega in družinskega zavetnika kot spretno govorniško potezo, ki jo je humanist uporabil predvsem za samoupodabljanje na renesančnem govorniškem odru.

Ključne besede: Peter Pavel Vergerij Starejši, sv. Hieronim, zavetnik, govor, humanistično samoupodabljanje

\section{Introduction}

During 1390-1408, Pier Paolo Vergerio, one of the leading humanists of his generation, delivered at least ten public orations in honour of Saint Jerome. His Sermones pro Sancto Hieronymo counts as the earliest examples of the classicizing orations (panegyrics) in devotional public oratory (O'Malley 1979, 86). ${ }^{1}$ Following the classical precepts, rather than the traditional thematic form of late medieval speeches, Vergerio's orations illustrate one of the most discernible aspects of the humanists' amalgamation of classicizing elements and hagiography. ${ }^{2}$ The omission of biblical quotations, which otherwise guided thematic sermons, opened the ground for humanist innovation and self-fashioning. Accordingly, the contents of the orations ceased to focus on the saints' performances of miracles, and instead replaced them with their lives and deeds, interpreted in conformity with the preferences of their audience.

Vergerio began his public speaking career in Padua around $1390 .{ }^{3}$ His tradition of annual orations in honour of St. Jerome probably began around the same time, although the precise year has not yet been identified. In his Ep. 42, Vergerio states

1 On epideictic oratory, see Pernot, La Rhétorique de l'éloge dans le monde gréco-romain (1993) or Kennedy (1999) for a summarization. For humanist oratory in imitation of Ciceronian handbooks, see Witt 1990, and for humanist devotional oratory, McManamon's Funeral Oratory of the Papal Court (2017). When referring to the format of Vergerio's Sermones, the secondary scholarship employs different terminology. The expressions ,sermon,' ,oration', ,speech', and ,panegyric' are used interchangeably by the previous scholarship; I will refer to these texts as sermones, since this is the label used in the manuscripts.

2 The thematic form appeared in the late twelfth century and coincides with the birth of Scholasticism. The central study of the theme remains Caplan's Of Eloquence (1970). For Latin medieval preaching see Modern Questions About Medieval Sermons by Nicole Bériou and David D'Avray (1994).

3 There is no evidence of any public activity before this time. These early speeches are Vergerio's judicial oration in defense of Francesco Novello da Carrara's lieutenant Bartolomeo Cermisone (1390-1392), an oration celebrating Francesco Novello's recovery of Padua (1392) and the well-known funeral oration for Francesco Carrara the Elder (1393) (Katchmer 1998, 15; Simoniti 1979, 27-29). For Vergerio's biography, see Katchmer (1998, 1-77). 
that his practice started four years before the letter's composition (Smith 1934, 91). If Smith's dating of the letter to 1392-1394, more probably to 1394 , is correct, Vergerio possibly delivered his first oration in 1390. Two of the orations are dated in the manuscripts: Sermo 5 to 1392 and Sermo 9 to 1408 . Sermo 8 can be dated to 1406, based on internal evidence (Robey 1973, 27). The exact order of the orations, however, does not depend on manuscript numbering and remains unknown. ${ }^{4}$ Three of the orations were delivered in monastic environments $(1 ; 5$; 10), two were delivered close to Vergerio's hometown in Istria $(3 ; 6)$ (Robey 1973, 37), and Sermo 8 was delivered at the papal court in Rome.

In his panegyrics, Vergerio actively contributed to shaping the humanist cult of St. Jerome. As an active scholar in numerous fields, from the theory of education, canon law, and medicine to logic and rhetoric, Vergerio portrayed a similarly active figure of Jerome and called to the imitation of his countless virtues. He emphasized Jerome's erudition and piety and portrayed him as a pious scholar. Touching upon merely a few of his most famous miracles, Vergerio emphasized Jerome's human aspects and depicted him as a familiar figure, approachable for imitation of everyone. Vergerio's orations were circulated in numerous codices, often functioning as prefaces to Jerome's works. The orations became a new and influential model for the humanists' epideictic oratory. This made Vergerio's panegyrics so famous that they survived in many manuscripts and even in the first incunabula of Jerome's collected works.

While praising St. Jerome, Vergerio offers himself as a witness of the saint's excellence. In Serm. 5 and 8, and one of his letters, Vergerio explains that his inspiration to praise Jerome derives from his family's ancient tradition and his personal experience of Jerome's sanctity. ${ }^{5}$ On these grounds, he vowed to annually deliver a public oration in the saint's honour on his feast-day (McManamon 1985, 185). His vow is often referred to at the beginning of the orations' exordia. However, there is no information about Vergerio's family partaking in any specific rituals in honour of the saint, nor did St. Jerome remain the patron saint of the Vergerii family (Marinčič 2018, 13). Usually taken for granted, Vergerio's invocations of St. Jerome as his family patron have not been probed to a satisfactory degree by the existent scholarship. ${ }^{6}$ McManamon takes it at face value in his seminal edition and does not pause much at Vergerio's words. ${ }^{7}$

This paper, however, is meant to signal that Vergerio's appropriation of St. Jerome as his personal and family patron was his rhetorical device to add to the emotionality of his orations and contribute to his fame. On these grounds, I will discuss the unique features of Vergerio's authorial approach in his fifth pane-

4 I use the numbering and sequence of delivery suggested in McManamon's edition, which, due to different manuscript referencing, differs from the one used earlier by Robey and Smith.

Ep. 79 to Vergerio's father (Smith 1934, 186-187).

6 See the article by Marinčič (2018) for a welcome exception to this trend.

7 The full title of McMannamon's book is Pierpaolo Vergerio the Elder and Saint Jerome: An Edition and Translation of Sermones Pro Sancto Hieronymo (1999). 
gyric and compare it to his other panegyrics in honour of St. Jerome as well as to Vergerio's letters. Taking the orations in parallel with later panegyrics to St. Jerome composed by other humanists, I will illustrate Vergerio's appropriation of St. Jerome as a smart rhetoric device to establish himself on the humanist stage of classicizing rhetoric.

\section{Departing From the Tradition: Sermon 5}

According to the manuscripts, Vergerio's fifth sermon was delivered in 1392 to Benedictine monks in Padua (McManamon 1985, 185). This is Vergerio's most extended oration, and, according to Robey, it may have been the earliest (Robey $1973,37)$. Indeed, the oration does not refer to any previous speeches, which is otherwise a systematic way for Vergerio to start the exordium. Although Robey's argument is based only on his opinion, according to which the oration is relatively immature in style and hesitant in its approach to the subject (37), the speech is the least coherent among Vergerio's orations and often jumps between the topics.

Moreover, Sermo 5 is famously unique owing to Vergerio's explicit declaration of his complete break with the thematic structure of the scholastic sermons. This might be another argument in favour of the oration being the first one. Vergerio straightforwardly draws attention to his omission of the usual biblical verse at the beginning of the sermon:

"With your kind permission, I will slightly depart today from the usual manner of delivering a sermon, and leaving aside the thematic verse from the Scripture (a convention that is no longer observed by the most up-todate-preachers), right at the beginning, I will call to my aid the most glorious Virgin." (McManamon 1999, 172)

Owing to the lack of materials, the veracity of Vergerio's claim that this was already part of contemporary practice cannot be established. Nevertheless, even though not a single example of sermons delivered from the pulpit and following classical norms has been found up to date, as O'Mally $(1979,86)$ and Knowles Frazier $(2005,213)$ report, Vergerio already used the new format in his earlier funeral orations. ${ }^{9}$ In any case, the emphasized opening remark served chiefly to underline his classicizing program.

Moving on, Vergerio inserted an emotional confession of his family's devotion to St. Jerome in a first-person narrative. He reported that his family arranged annual feasts in St. Jerome's honour as long as they could afford them:

„Cum bona venia vestra praetermiteram nunc parumper solitum morem sermocinandi, et, omisso themate (qui mos iam apud modernos deciderat) primo gloriossisimam virginem ad auxilium mihi vocabo. " (McManamon 1999, 171) I quote Vergerio's orations in McManamon's English translation, occasionally modified.

9 See note 3 . 
"They were accustomed for as long as their resources permitted them to offer a solemn feast for the poor of the city. Moreover, they used to remember that their own ancestors had consistently performed the same service on this feast day. /.../ If ever fortune should look and smile upon me once again, I will not hesitate to revive this ancient custom of our family. " (McManamon 1999, 178-179) ${ }^{10}$

He then vowed to continue with the tradition to honour St. Jerome on his name day and started to ponder which of his many virtues he should praise. Vergerio does not share the information about the aftermath of his family's devotion in this oration; however, he recounts it in Sermo 8 (McManamon 1985, 224). As a result of Jerome's divine intercession, Vergerio's family survived the attacks of Genoans on their hometown, Justinopolis (now Koper, in Slovenia). This deepened much further their already ardent devotion, cultivated most notably by Vergerio's father, who, at the time of Sermo 8, according to Vergerio, was just recently deceased. After his father's death, Vergerio presented himself as the sole heir to the family tradition, whereby he vowed to deliver a speech in the saint's honour each year. The oration becomes highly emotional when Vergerio speaks of his father's legacy, and its style frequently borders on theatricality.

However, one might wonder whether Vergerio was, in fact, »[n]ourished in an environment that saw the family as honoured clients of a powerful heavenly patron [and] committed himself to a public act of devotion to Jerome for the rest of his life" on this ground, as stated by McManamon in his seminal work $(1999,16)$. There is no actual evidence about St. Jerome as the patron saint of the Vergerii family (Marinčič 2018, 13) or their special rituals in honour of the saint in Justinopolis. The patron saints of the town were, at the time, St. Nazarius and St. Alexandrus, ${ }^{11}$ who, in contrast to St. Jerome, are not mentioned in any of Vergerio's extant works, nor his letters. ${ }^{12}$ However, as indicated by Frazier, appropriation of ,personal saints' was the standard humanist practice (Frazier 2005, 16). Vergerio probably familiarized himself with the humanist cult of St. Jerome in the learned university milieus of Florence, Bologna, and Padua. Jerome was an ideal epitome for the humanists' Christian universalism, owing to his simultaneous enthusiasm for the classical authors and biblical exegesis.

10 »[S]olebant parentes mei, dum fortuna laetaeque res starent, atque id a suis fieri solitum commemorabant perpetuo hoc ipso festo die, cum sacra ritu debito et solito more peracta essent, sollemne convivium pauperibus facere. Si quando tamen fortuna placide vultu faverit, ne vetustum quidem morem familiae nostrae praetermittam.« (McManamon 1999, 176-177)

11 The cult of these two saints was in fact very popular in Justinopolis. The requisition of St. Nazarius's relics was, for example, the main calamity during the attack of Genovese on Koper which also forced the Vergerio family to leave their hometown. St. Alexander's relics are preserved in the cathedral church of Koper (Smith 1934, 506).

12 Although Smith reports on four hymns in honor of St. Nazarius in Vergerio's Epistolario, he already emphasizes that they were wrongly attributed to Vergerio, since they were added to one of the manuscripts with his Sermones. They were, in fact, written in 1422 to celebrate the return of the relics to Koper, arranged by archbishop of Genoa, Pileo de Marini (Smith 1934, 506). The hymns are listed as anonymous in McManamon, "Research Aids: Pierpaolo Vergerio the Elder." 
Moreover, in their lively interest for textual criticism, the humanists also fiercely transcribed and compiled his letters (Cain 2009, 225). Devotional texts, transcription of a saint's works, or production of his vitae served as an ex-voto to the saint. Passing through Italian cities, courts, and university towns, thus encountering different local cultures, humanists depended on their rhetorical abilities, and they tailored them according to the circumstances. Thus, looking closer into the contexts of Serm. 5 and 8 and comparing them with the circumstances of deliveries of other orations by Vergerio might shed light upon some additional arguments for his references to the family and personality cult of St. Jerome precisely in these two sermons.

\section{Effigiem mihi confingo: Sermons 5 and 8 Among the Other Vergerio's Orations}

Vergerio's Sermones were treated as a corpus by the previous scholarship, and the specific contents or backgrounds of the individual orations have not been analyzed in much depth. Despite their differences, McManamon's edition and English translation of Vergerio's speeches do not observe Vergerio's orations as individual texts. Vergerio's works are looked upon in the same way by Rice's monograph on the cult of St. Jerome in the Renaissance (1988), and the orations are treated merely as a product of a new rhetorical style, intended to promote the revised image of St. Jerome. ${ }^{13}$ However, by examining the orations one by one as individual pieces, it is possible to grasp Vergerio's program of remodelling the image of St. Jerome according to his different audiences. As there are no other humanist authors who produced more than one oration on St. Jerome, Vergerio's orations offer a unique opportunity to inspect the changes of his rhetorical approach according to the contexts in which the orations were delivered, by the same author and in praise of the same subject. A captivating performance was essential for the epideictic genre of Vergerio's speeches, which therefore focused primarily on the audience. Vergerio aptly devised the rhetorical topoi and shaped the entire contents of his orations to secure the audience's sympathy. The imitation of examples is indeed the chief motto of his work. Nevertheless, the examples given in the orations are different when it comes to an audience of different social backgrounds.

For example, in the orations delivered to monks, Vergerio demonstrates praise to be instructional on the grounds of Jerome's biographies, which praised the desert fathers. Writing about the lives of these, Jerome was motivated to imitate their austerity as well. ${ }^{14}$ According to his teaching, Jerome's lifestyle is highlighted, and

13 McManamon looks into the classicizing features of Vergerio's oratory also in his monograph Pierpaolo Vergerio the Elder: The Humanist as Orator (1996) and in his earlier article „Pier Paolo Vergerio (the Elder) and the Beginnings of the Humanist Cult of Jerome" (1985).

14 See Bobovnik and Derhard 2020, 3-31 on Jerome as a chief promotor of the philosophy of desert ascetics. 
the Benedictine monks are exhorted to imitate it. Not only does Vergerio emphasize Jerome's extreme endurance and piety while enumerating his deeds, but the orations also echo criticism and blame, clearly in line with the reform movement inside religious orders (McManamon 1985, 354). In contrast, speaking in front of lay audiences, Vergerio paraphrased classical authors ${ }^{15}$ and illustrated praise as an already ancient practice, which taught the examples for imitation.

In the orations delivered in Istria (Serm. 3; 6), Vergerio argued that owing to the location of Jerome's birthplace near ,this particular region' (regio ista), the audience, in this case, lay locals has a special duty to venerate the saint and imitate his deeds. ${ }^{16}$ He portrayed Jerome as one of the illustrious fellow citizens, only that he is immensely more praiseworthy and learned. He emphasized the saint's shared humanity with the audience and characterized him in terms of the audience's intercessor with God. If the audience joins Vergerio in faithful praise of St. Jerome, they, now living close to Jerome's earthly residence, will make themselves »members of his heavenly lineage " in the afterlife (Mcmannamon 189, 355). However, even though Vergerio sided with the audience and depicted himself as one of the local populace, he spoke here in a considerably less personal tone than in Serm. 5 and 8 . However, his orations echo the language of late-antique local cults, ${ }^{17}$ his Jerome does not figure as a ,national' saint of Dalmatia. ${ }^{18}$ Moreover, in Sermo 3, Vergerio carefully warns against an affection towards St. Jerome merely on account of his origins:

»But indeed, neither proximity of birth, nor blood relationship, nor any earthly bond renders us acceptable and gratifying to the saints of God; only moral integrity, sanctity of life, and spiritual devotion can do that. As a matter of fact, we can please the saints only by doing the same things that made the saints themselves pleasing to God." (McManamon 1999, 99) ${ }^{19}$

Going even further, in Sermo 6, Vergerio delivered a semi-historical lecture about a historically unfounded local veneration based on resemblances of the names of a small nearby village Stregna and Jerome's Stridon. ${ }^{20}$ He labels it as , a local rumour' (dictum est) and straightforwardly condemns it. Jerome was born in a ,place nearby (hinc proximo loco), but not in Stregna, the village closest to Vergerio's hometown

15 E.g. Ovid in Serm. 2 (McManamon 1999, 143) or Seneca in Ep. 78 (McManamon 1985, 185).

16 The infamous question of the exact location of Jerome's birthplace, Stridon, remains unanswered. On various placements of Stridon by the humanists, see the article by Grubišić $(2008,227-298)$.

17 For the function of medieval cults of saints see, for instance, Brown's The Cult of Saints (1989), and Klaniczay, „Using Saint: Intercession, Healing, Sanctity“ (2014, 217-237).

18 On this topic, see the article by Ivić „Jerome comes home“ (2016, 618-644), and her dissertation "The Birth of the National Saint: The Cult of St. Jerome in Late Medieval Dalmatia" (2020). On the cult of St. Jerome among the Slavs, see Verkholantsev, The Slavic Letters of St. Jerome: The History of the Legend and Its Legacy, or, How the Translator of the Vulgate Became an Apostle of the Slavs (2014).

19 „Verum enimvero non ortus propinquitas, non coniunctio sanguinis, non ulla mundialis necessitudo, sed honestas morum, vitae sanctitas, ac mentis devotio Sanctis Dei acceptabiles nos reddit et gratos. Per ea etenim sola placere ipsis possumus per quae et ipsi Deo placuerunt. (McManamon 1999, 198)

20 For the translation of the entire passage to Slovenian, see Marinčič 2018, 14. 
(McManamon 1999, 201). Additionally, Vergerio does not honour St. Jerome as a national saint, as was the practice within the Dalmatian cult of the saint. ${ }^{21}$ Moreover, in none of the panegyrics from Istria did he ever refer to St. Jerome as his family's patron saint, as he does in Serm. 5 and 8. One might ask why Vergerio opted to denounce local rumours rather than referring to his family's devotion to the saint, particularly in these orations delivered closest to his hometown.

It might not be too far-fetched to infer some explanations from the same venues of the orations' performances. Compared to the orations delivered in the small provincial towns of Istria, the circumstance of Serm. 5 and 8 were far more critical. Even though Sermo 5 was delivered in front of monks, it was among Vergerio's first orations (if not the very first one), which made it significant for his rhetorical career. His arguments on account of the family tradition of praise would help him establish himself as a premier member of Jerome's cult and add to his praise's rhetorical ,veracity. Appealing to the traditional family veneration served as grounds for a popular epideictic device already part of the ancient oratory. ${ }^{22}$ Indeed, the cult of St. Jerome was already firmly established by the time Vergerio wrote his orations; however, it has to be kept in mind that Vergerio was promoting a particular representation of the saint - that of a learned orator and translator, including a refurbished version of Jerome's dream. ${ }^{23} \mathrm{He}$ referred to his family as already ,veteran' followers of Jerome's cult and contributed to his fame.

Vergerio's self-fashioning is even more evident concerning the particular circumstance of Sermo 8. This oration was delivered in front of the papal Curia in 1406. It was probably one of the most renowned orations during the Renaissance, as it was included as a biographical appendix to the first edition of Jerome's works published in Rome in 1468. It belonged among Vergerio's most accomplished orations and was seen as advocacy of humanist studies by the later Renaissance authors. Vergerio primarily reflected on Jerome's dream in this sermon and offered a revised humanist interpretation (Belting 2014, 6). According to his own words, he described how Jerome continued to read the classics, but not as ardently as the Scripture (McManamon 1999, 155).

Moreover, he inferred that St. Jerome merely applied his classical studies in the service of his biblical work. This panegyric therefore comprised a call for humanism in the service of the religious community, announcing that the humanist studies would prepare learned clergy capable of moral reform by living exemplary lives. ${ }^{24}$ Where could Vergerio more appropriately insert an emotional appeal to his fam-

21 On Slavic cult of St. Jerome, see Verkholantsev 2014 and Badurina-Stipčević 2013, 17-26.

22 The canon of epideictic topoi, listed by Menander, was transmitted to the humanists by Priscian's handbooks as loca laudis vel vituperationis (Simoniti 1979, 25). For the impact of humanist classicizing oratory on the preachers of the Catholic Reformation see, for instance, Visočnik 2018.

23 Ep. 22. For English translation, see Wright (1933, 52-157).

24 In ecclesiastical context, Vergerio used the image of St. Jerome in order to contrast him to the corrupted practice of the clergy of his time. He especially criticized the preachers, accusing them of delivering empty words in front of their audience while not providing an example of moral life themselves (McManamon, 115-29). 
ily tradition, boosted by the reference to his recently deceased father, if not in the refined background of the papal court and campaigning for classical learning?

Similar creation of saintly patronage was frequent in the Late Middle Ages, and the saints whose sanctity one heard of being experienced by those close to them immediately became more popular (Vauchez 1997, 133). On the other hand, there was no need to bring the saint closer by referring to his devotion in the orations in Istria; a local veneration was probably present there already in the late medieval period. ${ }^{25}$ Vergerio did not need an additional device to bring Jerome's cult closer - a medieval cult of St. Jerome as a pious penitent saint was already widely disseminated within the area. What Vergerio instead focused on in his orations in Istria is Jerome's reinterpreted image of a learned scholar and translator. Consequently, it was much more expected of Vergerio to exploit the proximity of the saint's birthplace to display his linguistic knowledge by exposing the erroneous theory of Stregna as Stridon. In contrast, while speaking in faraway Padua or Rome and aiming to establish himself as Jerome's spokesperson, a reference to the traditional family devotion to St. Jerome would likely add to Vergerio's rhetorical authority. He did not argue his family's or his father's devotion to the saint, yet his affection for the cult was expressed with sufficient emotionality to make the oration effective.

\section{Patronus meus: St. Jerome in the Context of Vergerio's Letters}

Even if Vergerio did not report the reasons for his family's extraordinary devotion to St. Jerome in his orations, he described them in one of his letters, Ep. 79, addressed to his father and dated in the year 1397 (Smith 1934, 186-87). The letter begins almost verbatim as some of Vergerio's orations. He first asserts his rhetorical inadequacy to the subject yet immediately pledges to carry on with his practice of public preaching since it is a way to repay his father's love. Then he makes several passionate exclamations, urging his father to honour St. Jerome and underlining it with a paraphrase from Seneca: »[T]o receive a favour without a single word of thanks comes close to denying it. $"{ }^{26}$ Afterwards he recounts the story about Jerome's intercession but placing it at his father's lips as if it were a recollection of something his father has once told him himself. Further, he inserts a series of rhetorical questions and reaching the climax by an appeal to St. Jerome as the one who saved the life of Vergerio's father:

25 The Franciscan monastery in Justinopolis at the time belonged to the Dalmatian Franciscan province of St. Jerome. This is also reflected by a large number of local churches, consecrated to St. Jerome, which was the reason for a recent suggestion to declare St. Jerome for the main patron of the present-day bishopric of Koper (Valenčič 2007, 123-154).

26 „Proximus est enim neganti beneficium is qui tacet. " (Smith 1934, 186). Cf. Seneca, De Beneficiis 2.1.: "[P]roximus est a negante, qui dubitavit, nullamque iniit gratiam. " For the entire translation of the letter, see Božič 2020, 90-91. 
"Who was it that led us out alive from so many traps laid against us during that wartime clash, when everything was filled with terror and was collapsing? Who was it that carried us safe and sound from the devastation and smouldering ashes of our pillaged homeland? /.../ Last but not least, who was it that saved your life after you had been condemned to death and exposed to many great dangers if not the one to whom you have entrusted your life? « (Smith 1934, 186) ${ }^{27}$

The letter closely echoes Serm. 5 and 8, and Vergerio sometimes repeats entire phrases from the orations. Curiously enough, Vergerio uses the same admonitions he used in his oration to the monks, and he seems to be reminding his father, supposedly the initiator of the family's devotion to St. Jerome, why the saint deserved to be praised by the family. One might reasonably wonder why Vergerio's father would need to be reminded of the family tradition.

Vergerio's letter belongs among the typical humanist stylistic letters that form their authors' image as they each wanted it conveyed to posterity. It was not unusual for the humanist authors to combine themes and even phrases from their orations with those from the letters and vice versa. Ep. 79 is likely to have been designed precisely to enforce Vergerio's auto-portrayal as Jerome's disciple. The phrases that are repeated in his public oratory and stylistic letters are likely to serve as self-fashioning rhetoric devices, especially in the works that were expected to be disseminated or even included within the significant works.

Moreover, some other letters of Vergerio's illustrate his inclination to the etiological myths, a literalization of his hometown origins, and his aspirations to be bound with St. Jerome's figure. Although pretending to disdain some of his letters, Vergerio was quite concerned with the local history. ${ }^{28} \mathrm{He}$ was also engaged in discussions about the origins of the name Justinopolis, claiming that the city was named by Emperor Justinian II (565-578). Justinian reinforced and regulated the original Roman settlement of Aegida or Capris, inhabited by fugitives of the Langobardic invasion at the time of his arrival. Vergerio describes the myth in one of his letters, where he also states that Justinopolis has now fallen into moral decay and ruins despite its noble history. The only reason it could be praised for nowadays is its proximity to Jerome's birthplace:

„Because you see, even some obscure places had brought up great men, and celebrated cities ignoble ones, since, as it is indeed attested, it usually happens more often that extreme brilliance springs from an oppressed

27 "[Q]uis nos belli fragore, quo cuncta terrebantur, cuncta ruebant, ex tot paratis insidiis vivos eripuit? Quis ex patrie, populate ruinis, ardentis cineribus, sanos et tutos evexit? Aut quis patrium solum egressos ac alineno benigne receptos olim in patriam et revexit ac in tuto reposuit? Quis denique caput tuum damnatum, tot periculis expositum, nisi is cui fuerat commendatum, servavit incolume? « For leaving his post in order to flee, Vergerio's father was at first condemned to death. Upon their return to Justinopolis in $\mathbf{1 4 8 3}$ he was acquitted, but the family never rose to the same distinguished position it held before.

28 Vergerio's two works that focus primarily on the region close to his hometown are De situ lustinopolis and De republica Venetorum. 
and unknown place. In this regard, you could give many ancient examples, yet you could hardly quote any worthier or one that would be dearer to me, than, as you have remarked, St. Jerome, my patron, ,the star of the Church', to praise him in your words, and, as you ought to have added, of exceptional learning. He was born not far from my fatherland's borders in a humble place, which became therefore revered before many other most splendid cities." (Smith 1934, 145) ${ }^{29}$

In this passage, Vergerio refers to one of the common topoi of the epideictic genre, which links the subject of praise to his birthplace. As recommended by the handbooks, when the homeland of the subject praised was already remarkable, the panegyrist should refer to it as foretelling the glory of the one being praised. In contrast, if their birthplace was humble or disreputable, this should be emphasized to point out how gloriously the subject being praised surpassed their little background (Kennedy 2003, 156). The reference clearly illustrates Vergerio's intentions and is underlined in his orations from Istria, where he highlights Jerome having departed for Rome to become »better and more learned», despite his love for his homeland (McManamon 1999, 156). ${ }^{30}$ By emphasizing the proximity of St. Jerome's origins and his birth town in this letter, Vergerio, in a way, binds himself with his successful compatriot. It was not only Jerome who rose above his humble origins but also Vergerio, coming from the same region-aligning his family and upbringing to a famous figure of an erudite theologian added to his promotion. Emphasis on the saint's humanist activities presented St. Jerome as a model for imitation. Vergerio's self-representation as a paragon of Jerome's cult also shaped his portrait - in close resemblance to that of his patron.

\section{Closing Remarks: Vergerio's Orations in Parallel With Other Panegyrics on St. Jerome}

Vergerio's other panegyrics and letters are not only texts that invite for a closer examination, especially in a comparative context. By focusing on Jerome as the subject of praise, I have been able to locate a set of epideictic orations composed throughout the fifteenth century. The first one of these was delivered in 1410 in Padua by Nicolaus (Niccolò) Bonavia of Lucca. ${ }^{31}$ Soon after that, there was a simi-

29 "Sed, ut vix ullum dignius, ita nullum michi gratius adhibere potuisses quam quod Hieronymum memoras, patronum meum, Ecclesie, ut voce tua suo cum titulo decorem, sidus, et, ut adicere debueras, summum doctrine, quem non procul a patrie mee finibus humilis locus sed hoc uno plurimis amplissimis urbibus." (Ep. 62, to Giovanni Zabarella)

30 The passage in fact turned out to be extremely far-reaching. Owing to Vergerio's self-representation, the famous Italian historian Fabio Biondo (1392-1463) listed Vergerio and Jerome as the most prominent people from the region, and on this grounds classified Istria as an Italian province.

31 Biographical information about Bonavia is sparse. So far, the only detail I have been able to gather is that he was an erudite poet and at the time of delivering the oration, a student at the University of Padua. His oration is preserved in two manuscripts: Vatican library, BAV Vat. lat. $59943 \mathrm{r}-7 \mathrm{v}$, and in Biblioteca Ambrosiana, R 92 sup. 2, 13r-17r. 
lar oration in praise of St. Jerome in Siena, no later than 1447, by Agostino Dati. ${ }^{32}$ They offer a contrast to Vergerio's earlier work, and none of them represents Jerome as the personal patron of the authors or their families. Bonavia's oration was delivered in 1410 in Padua (Rice 1988, 95). Instead of offering a personal motivation to praise St. Jerome, Bonavia employs the Platonic doctrine of the four cardinal virtues and introduces Jerome's deeds as evidence of these virtues. His oration thus closely adheres to the scheme of ancient funerary encomia and is exceptionally detailed when it comes to Jerome's biographical details. Dati's oration offers a similar example and turns into a catalogue of Jerome's translations. Again, there is no reference to Dati's devotion to St. Jerome; on the contrary, the oration is characterized by a rather detached tone.

Another oration was delivered in Verona in 1453 by one of the first female humanists, Isotta Nogarola. ${ }^{33}$ Instead of a detailed biography, Nogarola focuses on Jerome's persistent pursuit of knowledge. Going against Jerome's emphasis in his famous letter to Eustochium, ${ }^{34}$ she promoted his learning over the virtue of virginity, thus justifying her scholarly ambitions and using the oration as a personal apology. Nogarola exploited the rhetoric tropes to position herself as a female author. Even though she did not offer her audience any explicit incentive to imitate the saint, the human quality of her portrayal of St. Jerome recalls Vergerio's patron. However, compared to Vergerio's works, these later pieces were less vivid in terms of authorial presence and the authors' affection for St. Jerome. These orators did not offer any argumentation for their praise, and they did not present it as part of their devotion to the saint. Even if the pieces are long and meticulously crafted, they inspire far less emotional effect than Vergerio's narrative. Curiously, however, none of these panegyrics attained such wide promulgation as did Vergerio's; they often survived in a unique version. Vergerio's panegyrics, in contrast, circulated in several manuscripts, even though none of them includes all ten orations (McMannamon 1999, 137). Their presence in the volumes, originating from Northern Italy, suggests that the students often turned to them as models for their rhetorical compositions, regardless of their interest in St. Jerome.

The humanist scholars already acknowledged this variety of epideictic oratory in praise of civil or ecclesiastical governors. "Nobody remains unaware that panegyrics reflect not their subjects' merits, but their author's ingenuity, « stated Desiderius Erasmus (Rundle 2007, 159). ${ }^{35}$ Was the personal appropriation of St. Jerome and his representation as a patron saint one of the critical features of

32 Agostino Dati: Incipit Oratio prima de laudibus divi Hieronymi. For a summary of his life, see Dizionario Biografico degli Italiani (1987, 15-21).

33 The oration was composed as a public welcome of the new Veronese bishop Ermolao Barbaro. It is translated to English in Nogarola's Complete Writings, edited by Margeret L. King and Diana Maury Robin (2003, 159-74).

$34 \quad$ Ep. 22.7.

35 „Ac minus quidem laedunt Poetae Rhetoresque, quorum nemini iam ignotum est institutum, Principum laudes non ex ipsorum meritis, sed ex suo metiri ingenio. " (Desiderius Erasmus, Institutio Principis Christiani II, 2.4, 1335-1337 [Rundle 2007, 159]). 
Vergerio's authorship? It is impossible to speculate whether Nogarola's oration would have made it to later collections were it not composed by a female oratrix, and therefore disseminated primarily in her local background. Nevertheless, Vergerio's affectionate representation of St. Jerome as his and a humanist patron saint beyond any doubt promoted the dissemination of the famous Sermo 8, as well as contributed to Vergerio's popularity as a rhetorician. The utilization of the historical background to give authority to a speech was widely acknowledged already by contemporary writers. To quote another famous humanist, Leonardo Bruni openly renounced the historical fidelity of praise while commenting on his panegyric to Florence: "History must follow the truth, but praise raises many things above the truth. " $(1998,487-88)^{36}$ Vergerio masterly raised his Jerome above all. Regardless of the veracity of his family devotion to St. Jerome, his references are convincingly exploited in order to point out his path to proper veneration of the saint: not only through imitations of Jerome's piety but also, and especially, through the emulation of his eloquence.

\section{References}

Primary sources

Bonavia, Niccolò. 1416. Oratio de leronimi laudibus habita coram episcopis anno 1410 Patavii. Vatican Library, Biblioteca Apostolica Vaticana Vat. lat. 5994 3r-7v; Biblioteca Ambrosiana, R 92 sup.; $2,13 r$.

Dati, Augustino. 1502. Incipit Oratio prima de laudibus divi Hieronymi. In: Augustini dati senensis opera, fol. 56b. Siena: Ex archetypo per Symionem Nicolai Nardi.

McManamon, John M, ed. 1999. Pierpaolo Vergerio the Elder and Saint Jerome: An Edition and Translation of Sermones pro Sancto Hieronymo. Tempe, AR: Center for Medieval and Renaissance Studies.

Smith, Leonardo, ed. 1934. Epistolario di Pier Paolo Vergerio. Rome: Tipografia del Senato.

\section{Secondary sources}

Badurina-Stipčević, Vesna. 2013. Legenda o Jeronimu u starijoj hrvatskoj književnoj tradiciji [Jerome's legend in old Croatian literary tradition]. Wiener Slawistischer Almanach 85:17-26.

Belting, Hans. 2014. St. Jerome in Venice: Giovanni Bellini and the Dream of Solitary Life. I Tatti Studies in the Italian Renaissance 17, no. 1:5-33.
Bobovnik, Nena, and Gina Derhard. 2020. Eremita alter philosophus: Understanding Ascesis in Pagan and Christian Philosophy. Clotho 2, no. 1:5-31.

Božič, Anja. 2020. Praising St. Jerome or Praising Eloquence: Pier Paolo Vergerio's Sermones pro Sancto Hieronymo and His Letters. MA Thesis, Central European University.

Brown, Peter. 1989. Society and the Holy in Late Antiquity. Berkeley: University of California Press.

Cain, Andrew. 2009. The Letters of Jerome: Asceticism, Biblical Exegesis, and the Construction of Christian Authority in Late Antiquity. Oxford: Oxford University Press.

Caplan, Harry. 1970. Of Eloquence: Studies in Ancient and Mediaeval Rhetoric. Ithaca, NY: Cornell University Press.

D’Avray, David, and Nicole Bériou. 1994. Modern Questions about Medieval Sermons: Essays on Marriage, Death, History and Sanctity. Spoleto: CISAM.

Grubišić, Vinko. 2008. Trojica humanista o rodnome mjestu svetog Jeronima: Flavio Biondo, Marko Marulić i José De Espinoza De Sigüenza [Three humanists about the birthplace of St. Jerome: Flavio Biondo, Marko Marulić and José De Espinoza De Sigüenza]. Colloquia Maruliana 17:227-298.

36 „Aliud est historia aliud laudatio. Historia quidem veritatem sequi debet, laudatio verum multa supra veritatem extolit.« L. Bruni Epistolarum Libri VIII, ed. L. Mehus (Florence, 1714), Ep. 8.4. 
Ivić, Ines. 2016. Jerome Comes Home: The Cult of Saint Jerome in Late Medieval Dalmatia. Hungarian Historical Review 5, no. 3:618-644.

Katchmer, Michael. 1998. Pier Paolo Vergerio and the Paulus, a Latin Comedy. New York: Peter Lang Publishing.

Kennedy, George. 1999. Classical Rhetoric \& Its Christian \& Secular Tradition from Ancient to Modern Times. Chapel Hill: The University of North Carolina Press.

Klaniczay, Gábor. 2014. Using Saint: Intercession, Healing, Sanctity. In: John Arnold, ed. The Oxford Handbook of Medieval Christianity, 217237. Oxford: Oxford University Press.

Knowles Frazier, Alison. 2005. Possible Lives: Authors and Saints in Renaissance Italy. New York: Columbia University Press.

Marinčič, Marko. 2018. Amore patriae teneri non potuit: dva Vergerija o Hieronimu in mejah lokalnega patriotizma [Amore patriae teneri non potuit: Two Vergerios about Jerome and the limits of local patriotism]. In: Gregor Pobežin and Peter Štoka, ed. Secretarii Actiones Petri Pauli Vergerii, 10-25. Bibliotheca lustinopolitana 9. Koper: Osrednja knjižnica Srečka Vilharja.

McManamon, John M. 1996. Pierpaolo Vergerio the Elder: The Humanist as Orator. Tempe, AZ: Medieval and Renaissance Texts and Studies.

- - - 1985. Pier Paolo Vergerio (the Elder) and the Beginnings of the Humanist Cult of Jerome. The Catholic Review 71:3-32.

- - - 2017. Funeral Oratory and the Cultural Ideals of Italian Humanism. Chapel Hill, NC: University of North Carolina Press.

O'Malley, John W. 1979. Praise and Blame in Renaissance Rome: Rhetoric, Doctrine, and Reform in the Sacred Orators of the Papal Court, c. 1450-1521. Durham, NC: Duke University Press.

Pernot, Laurent. 1993. La Rhétorique de l'éloge dans le monde gréco-romain. Paris: Institut des Études Augustiniennes.

Rice, Eugene F. 1988. Saint Jerome in the Renaissance. Baltimore: John Hopkins University Press.

Robey, David. 1973. P. P. Vergerio The Elder: Re- publicanism and Civic Values in the Work of an Early Humanist. Past\&Present 58:3-37.

Rundle, David. 1998. "Not so Much Praise as Precept«: Erasmus, Panegyric, and the Renaissance Art of Teaching Princes. In: Yun Lee Too and Niall Livingstone, eds. Pedagogy and Power: Rhetorics of Classical Learning, 148-69. Cambridge: Cambridge University Press.

Russell, Donald A., and Nigel G. Wilson. 1981. Menander Rhetor. Oxford: Clarendon Press.

Simoniti, Primož. 1979. Humanizem na Slovenskem in slovenski humanisti do srede 16. stoletja [Humanism in Slovenia and Slovenian Humanists by the mid- $16^{\text {th }}$ Century]. Ljubljana: Slovenska Matica.

Valenčič, Rafko. 2007. Sveti Hieronim - mož $s$ Krasa: prispevek $k$ ubikaciji Stridona, rojstnega kraja sv. Hieronima [St. Jerome - the man from the Karst: a contribution to the ubiety of Stridon, birthplace of St. Jerome]. Ljubljana: Družina; ZRC TEOF.

Vauchez, André. 1997. Sainthood in the Later Middle Ages. Translated by Jean Birrell. Cambridge: Cambridge University Press.

Verkholantsev, Julia. 2014. The Slavic Letters of St. Jerome: The History of the Legend and Its Legacy, or How the Translator of the Vulgate Became an Apostle of the Slavs. DeKalb, IL: NIU Press.

Visočnik, Julijana. 2018. Kvintilijanova Šola govorništva in pridiganje škofa Tomaža Hrena Hrena [Quintilianus' Institutionis Oratoriae and Sermons of the Bishop Tomaž Hren]. Bogoslovni vestnik 78, no.3:841-853.

Vitti, Paolo. 1987. Dati, Agostino. In: Dizionario Biografico degli Italiani. Vol. 33. Rome: Istituto della Enciclopedia italiana.

Witt, Ronald G. 1990. Civic Humanism and the Rebirth of the Ciceronian Oration. Modern Language Quarterly 51:171-78. 